А. А. Воробйова

\title{
СТРУКТУРНО-СЕМАНТИЧНІ ОСОБЛИВОСТІ СУФІКСАЛЬНИХ ІМЕННИКІВ У РОМАНІ «РАЙ. ЦЕНТР» ЛЮКО ДАШВАР
}

Воробйова А. А. Структурно-семантичні особливості суфіксальних іменників у романі «РАЙ. центр» Люко Дашвар.

У статті розглянуто похідні іменники, що утворені способом суфіксації й використані в сучасному прозовому творі. Установлено найпродуктивніші суфіксальні форманти та з'ясовано особливості семантики проаналізованих дериватів.

Ключові слова: словотвірна структура, семантика, суфіксальний дериват.

Воробйова А. А. Структурно-семантические особенности суффиксальных имен существительных в романе «РАЙ. центр» Люко Дашвар.

В статье рассмотрены производные имена существительные, образованные способом суффиксации и использованные в современном прозаическом произведении. Установлены самые продуктивные суффиксальные форманты и определены особенности семантики проанализированных дериватов.

Ключевые слова: словообразовательная структура, семантика, суффиксальный дериват.
() А. А. Воробйова, 2011.
$-566-$ 
Vorobyova A. A. Structural and semantic features of suffix nouns in a Luko Dashvar's novel «PARADIS. center».

Derivative nouns are considered in the article, which are formed by a suffixes method and used in modern prose work. The most productive suffix formants are set and the features of semantics of analysid derivates are certained.

Key words: word-formation structure, semantics, suffix derivate.

Останнім часом, за даними наукової літератури, вивчення українського словотвору здійснюється в таких напрямках: розмежування принципів морфемного i словотвірного аналізу (праці В. Горпинича, В. Грещука, Я. Закревської, С. Панцьо, О. Кубрякової, О. Ревзіної, Т. Вільчинської) [3,7,8,9], іменникова конфіксація української мови (П. Білоусенко, І. Іншакова, К. Качайло, О. Меркулова, Л. Стовбур) [1], типи словотвірних значень девербативів-іменників у віддієслівних гніздах iз значенням мислення (Г. Василевич) [2], структура складних іменників у контексті семантичного синтаксису (К. Городенська) [5; 6], словотворча структура i семантика складних слів у сучасній українській мові (Н. Клименко) [10], семантико-словотвірна структура гнізд слів із значенням почуття (Н. Тишківська) [11], суфіксальна експлікація конотації іменників (В. Говердовський) [4], особливості словотвірної семантики українських девербативів i деад'єктивів із нульовими суфіксами (Л. Третевич) [12] тощо. На сучасному етапі розвитку лінгвістичної думки приділяється увага вивченню мови прози та поезіі, зокрема словотвірної структури та семантики використаного автором складу слів, з огляду на те, що українська проза на початку XXI ст. збагатилася новими творами, дане дослідження є актуальним.

Мета статті: з’ясувати структурно-семантичні особливості суфіксальних іменників, використаних Люко Дашвар у романі «РАЙ. центр». Зібраний фактичний матеріал (393 похідні іменники) свідчить про те, що в сучасному прозовому творі найбільше зафіксовано суфіксальних похідних іменників (64\% від загальної кількості проаналізованих мовних одиниць). На другому місці стоїть спосіб основота словоскладання (15\%). Далі йдуть іменники, утворені безафіксним способом творення (9\%), та субстантивацією (8\%). Найменше виявилося конфіксальних структур (3\% від загальної кількості проаналізованих мовних одиниць) та префіксальних іменників (1\%).

Отже, у романі Люко Дашвар «РАЙ. центр» серед зафіксованих іменникових дериватів найбільше виявилося суфіксальних похідних слів (252 іменники), які проаналізовано з позиції їх семантики та словотвірної структури.

У творенні суфіксальних іменників беруть участь більше тридцяти морфем, найпродуктивнішими 3 яких виявилися -к-, -icmb, -ин-, -нн-, ец̧ь, -ник. Решта афіксів наявні у структурі не більше, як десяти слів кожен. Отже, опис мовного матеріалу здійснено в порядку спадання активності суфіксальних формантів. П'ята частина усіх проаналізованих іменників 
утворена за допомогою афікса -к-, вони поділяються на такі лексикосемантичні групи:

- назви предметів побуту: свічка (5) ${ }^{*}$, мотузка (6), кнопка (11), циигарка (11), картинка (12), книжка (24), сумка (25), картка (25), лялька (26), голка (30);

- найменування осіб: матінко (6), дівка (11), перукарка (15), хазяйка (16), білявка (20), дівчинка (26), коханка (37), касирка (46);

- назви результатів діяльності або окремої дії: забаганка (16), записка (17), згадка $(23,26)$, розвідка (23), думка (25), балачка (36);

- найменування місцевості: річка (5), хвилька (9), верхівка (11), бруківка (23), асфальтівка (56);

- назви будівель та їх частин: домівка (8), сходинка (13), лавка (17), кімнатка (21), стінка (21);

- найменування частин тіла людини й тварини: бровки $(6,33)$, шкірка (11), маківка (11), губка (44);

- назви певної їжі: картопелька (22), хавка (36), шоколадка (46);

- найменування транспортних засобів: автівка (11), машинка (22);

- назви посуду: пляшка (5, 20), чашка (26), склянка (46);

- найменування одягу: футболка (24), одежинка (40);

- назва тварини: тваринка (6);

- астрономічна назва: зірка (5).

Суфікс -ість є у словотвірній структурі двадцяти семи іменників, які називають:

- опредметнені абстрактні ознаки, притаманні певним особам i стосуються їх внутрішнього світу: гордість (30, 37), винахідливість (30), підсвідомість (40), розкутість (34), завзятість (38), унікальність (31), здатність (75);

- опредметнені абстрактні ознаки, притаманні певним особам і мають зовнішнє вираження: самотність (15), беззахисність (21), забитість (33, 56), майстерність (63), безпорадність (63), приналежність (39), приреченість (64);

- абстрактні назви об'єктивної дійсності: прикрість $(11,26)$, реальність (18), точність (21), якість (26), радість (33, 40), ияінність (39), нескінченність (51), безкінечність (54), очевидність (65), дохідність (66), вартість (67), нерухомість (67), діяльність (69).

Морфема -ин- утворює близько двадцяти іменників, які поділяємо на такі лексико-семантичні групи:

- назви осіб: дівчина (5), дитина (6), хлопчина (6), дружсна (31);

- найменування місцевості: чужина (38), вершина (76), глибина (6), середина (11), частина (5);

- назви конкретних предметів: сорочина (8), копійчина (22), милостиня (43), хлібина (56);

- найменування тварин: пташина (38); 
- назва приміщення: комірчина (15);

- найменування характерної зовнішньої ознаки особи: лисина (11);

- назва часового проміжку: давнина (28);

- абстрактна назва: відносини (11).

Суфікс -нн- наявний у словотвірній структурі іменників двох типів:

- ті, що називають результат певної діяльності: уподобання (32), гримання (21), розчарування (32), чергування (61), переконання (65), знущзання (85), хвилювання (77);

- ті, що називають опредметнену дію: спілкування (26), споживання (29), навчання (33), кохання (42), жадання (46), бажання (47), прибирання (76), тупцювання (77), пересування (78).

Іменники - назви осіб утворені за допомогою суфіксів -ець, -ник. Наприклад: 1) особи за професією або видом діяльності: випускник (57), двірник (64), рятівник (73), виробник (78), представник (84), чиновник (92), охоронець (55), обранець (66), ченець (92); 2) особи за характерними ознаками: незнайомецьь $(11,75)$, хлопець (16), збоченець (33), комсомолець (61), курець (77); 3) особи за місцем проживання: житец̧ь (14), украӥнецьь (39), виходецьь (80), прибулецьь (87).

Кілька дериватів, що у своїй словотвірній структурі мають такі афікси називають конкретні предмети: годинник (30), чайник (42), заварник (43), гаманецьь (34), прапорецьь (34), стілец̧ь (85); та певну місцевість: чагарник (89), заповідник (92).

Майже однакову кількість похідних іменникових слів утворюють форманти -ок, -чик, -н-, -ацій-. Зафіксовані в романі деривати можна теж поділити на лексико-семантичні групи:

- абстрактні назви: сигналізащія (11), реставращія (14), мотиваџія (20), коронація (28), аргументація (31), компенсація (31), інформація (32), агітація (36), організачія (60), заробіток (14, 28), підробіток (25), приробіток (37), випадок (31), чортівня (6), дурня (17), платня (32);

- назви істот зі значенням зменшеності або пестливості: купчик (15), братчик (29), синок (11), їжачок (6), кабанчик (89);

- найменування особи за характерними ознаками: виродок (17);

- назви певних приміщень: сарайчик (14), коридорчик (15, 45), притулок (13), куток (14), спальня (28), вітальня (30), кав'ярня (31), перукарня (32);

- найменування предметів побуту: диванчик (77), килимок (24);

- поодинокі назви: рослин - грибочок (22), частин тіла людини пальчик (29), транспортного засобу - пароплавчик (56), певного періоду доби - ранок (17), грошових одиниць - сотня (30).

У проаналізованих дериватах виокремлюються також форманти -ств-, -uu-, -icm, -uк, -ар, які теж характеризуються достатньою продуктивністю і наявні у словотвірній структурі таких груп слів:

- назви осіб за професією, політичними уподобаннями, 
характерними ознаками тощо: анархіст, суб'єктивіст, екзистенціаліст (37), песиміст (40), журналіст (67), шахіст (76), трудар (15), кухар (26), лікар (31), слоняра (41), пліткар (65), володар (83), паскудник (19), помічниия (36), служниия (38), n'яниия (61);

- збірні назви: цуарство (15), суспільство (39), жіноцттво (67), сімейство (69), гонорар (37);

- найменування певної місцевості: вулиия (16), столиия (29), дворик (14), скверик (32);

-абстрактні назви: нахабство (23), керівництво (61), кокетство (75);

- найменування конкретних предметів: спідниия $(5,6)$, дзвоник (27), пунктик (36);

- назва частини тіла людини: плечико (6);

- найменування спеціальних будівель, споруд: дзвіниия (15).

Невеликою активністю характеризуються суфікси -ищ-, -ук-, -от-, -ат-, -и-, -ощ-, -yc-, -л-, -ан, які простежуються у словотвірній структурі таких іменникових дериватів:

- назви істот 3 певними емоційними відтінками до основного значення: парубище (6), падлюка (20), гадюка (20), тварюка (62), голота (22, 25), сволота (93), янголята (23), серденята (56), бабия (32), бабуся (15), матуся (81), базікало (7);

- назви конкретних предметів 3 певними емоційними відтінками до основного значення: вудлище (34), каменюка (6), дверията (59), штаниі (6), бабло (22);

- найменування місцин 3 певними емоційними відтінками до основного значення: лежбище (41), звалище (111); $(8,31)$;

- абстрактні назви: глупота (9), гидота (13), нудота (28), видовище

- найменування почуттів людей: прикрощі $(37,64)$, веселощฺі (38), нутрощзі (69),

- назви частин тіла людини або тварини: оченята (27), крильце (23);

- найменування осіб за місцем проживання: кияни (5), селяни (22);

- збірна назва: трійия $(14,32)$;

- найменування певного шару активної лексики: матюк (21).

Поодинокі іменники утворені за допомогою формантів -очк-, -ак, -ир, -ер, -yp-, -ач, як правило, є назвами осіб за професією (бригадир (85), за видом діяльності (кандидатура (26), відвідувач (75)), за іншими ознаками 3 відтінком зменшеності-пестливості або збільшеностізгрубілості (жіночка (20), скотиняка (58), а також назвою конкретного предмета: електрошокер (12).

Отже, як показав аналіз фактичного матеріалу, похідні іменники у словотвірній структурі мають переважно суфікси, які утворюють нові слова або надають певного відтінку до основного значення слова. Щодо особливостей семантики, то усі досліджені деривати об'єднуються у такі ๑ А. А. А. Воробйова, 2011. 
тематичні групи: опредметнені абстрактні ознаки, притаманні певним особам і стосуються їх внутрішнього світу (гордість, розкутість), опредметнені абстрактні ознаки, притаманні певним особам i мають зовнішне вираження (самотність, беззахисність, забитість), абстрактні назви об'єктивної дійсності (якість, очевидність), назви осіб, місцевості, конкретних предметів, тварин, приміщень та їх частин, характерних зовнішніх ознак особи, часових проміжків, одягу, посуду, абстрактні назви.

\section{Література}

1. Білоусенко П. І. Нариси 3 історії українського словотворення (іменникові конфікси) / П. І. Білоусенко, І. О. Іншакова, К. А. Качайло, О. В. Меркулова, Л. М. Стовбур. - Запоріжжя - Кривий Ріг : ТОВ «ЛІПС» ЛТД, 2010. - 480 с.

2. Василевич Г. Я. Типи словотвірних значень девербативів-іменників у віддієслівних гніздах із значенням мислення / Г. Я. Василевич // Дослідження зі словотвору та лексикології. - К. : Вища школа, 1985. - C. 25-30.

3. Вільчинська Т. Морфемний і словотвірний аналіз у школі / Т. Вільчинська // Дивослово. -2003. - № 2. - С. 22-23.

4. Говердовський С. І. Про суфіксальну експлікацію конотації іменників / С. І. Говердовський // Мовознавство. - 1988. - № 3. - С. 54-59.

5. Городенська Г.К. Проблема виділення словотвірних категорій (на матеріалі іменника) / К. Г. Городенська // Мовознавство. - 1994. - № 6. - С. 25-28.

6. Городенська К. Г. Структура складних іменників у контексті семантичного синтаксису / К. Г. Городенська // Мовознавство. - 1988. - № 3. - С. 27-34.

7. Горпинич В. О. Словотворення і словотвір української мови : [навч. посібник (тексти лекцій)] / Володимир Олександрович Горпинич. - К., 1995. - 68 с.

8. Горпинич В. О. Сучасна українська літературна мова [Морфеміка. Словотвір. Морфонологія] / Володимир Олександрович Горпинич. - К : Вища школа, 1999. - 208 с.

9. Грещук В. В. Деякі теоретичні питання словотвірного значення / В. В. Грещук // Мовознавство. 1991. - № 3. - С. 34-42.

10. Клименко Н. Ф. Словотворча структура і семантика складних слів у сучасній українській мові / Ніна Федорівна Клименко. - К. : Наукова думка, 1984. - 251 с.

11. Тишківська Н. Я. Семантико-словотвірна структура гнізд слів із значенням почуття в українській мові / Н. Я. Тишківська // Ономастика і апелятиви [зб. наукових праць]. - Вип. 7. - Дніпропетровськ : ДДУ, 1999. - С. 213-215.

12. Третевич Л. М. Про особливості словотвірної семантики українських девербативів і деад'єктивів із нульовими суфіксами / Л. М. Третевич // Дослідження словотвору та лексикології. - К. : Вища школа, 1985. - C. 21-25.

Тут і далі по тексту мовний матеріал паспортизовано за книгою : Дашвар Люко РАЙ. центр [Текст]. - Харків : Книжковий Клуб «Клуб Сімейного Дозвілля», 2010. - 272 с. 